\title{
The Relationship between Perceived Organizational Justice and Cyberloafing: Evidence from a Public Hospital in Turkey
}

\author{
Emine Öğüt \\ Selcuk University, Konya, Turkey. \\ Mehmet Şahin \\ Selcuk University, Konya, Turkey. \\ M. Tahir Demirsel
}

Selcuk University, Konya, Turkey.

\section{Doi:10.5901/mjss.2013.v4n10p226}

\section{Abstract}

The aim of this research is to try to determine the role of organizational justice in the occurrence of cyberloafing behaviours, which have started to become a major problem for companies, by emphasizing the importance of the perception of organizational justice. The relationship between the lack of organizational justice, which is one of the significant problems of organizations, and cyberloafing has been tried to be determined. After the theoretical study, the relationship between perceived organizational justice and cyberloafing in hospitals has been analysed and it has been aimed to contribute to the solution of this problem by making some suggestions for the employers.

Keywords: Organizational justice, cyberloafing, the use of Internet

\section{Introduction}

Today, the Internet has become an indispensable element in people's personal and business lives. People have saved a lot of time for their work by the use of Internet. For this reason, people choose to do their work by using the Internet when they have chance. The greatest benefit of the Internet sometimes has an adverse effect. In other words, while the Internet enables people to save time, it sometimes leads to a loss of time. People lose a lot of time on the Internet by visiting sites that are not related to their work because the Internet world is an endless one. This loss of time causes a significant inefficiency at work.

Cyberloafing is the use of Internet and mobile technology during work hours for personal purposes (Bock \& Ho, 2009; Johnson \& Indvik, 2004; Lim, 2002; Mastrangelo, Everton, \& Jolton, 2006). Cyberloafing has started to become a major problem for businesses. The employees sometimes use the Internet for non-work related things while their managers suppose that they are working. As a result, work is delayed and the company loses efficiency. There are some different reasons under the cyberloafing behaviours. Checking personal e-mails, reading the daily news, watching or downloading obscene things and entering sharing sites are the most common cyberloafing behaviours. Cyberloafing behaviours are based on both personal and organizational reasons. When they are compared, organizational reasons are more important and difficult to solve than the personal ones. Especially the problems on the employee's perception of justice are the most important problems for the managers and they are needed to be solved urgently. When the employees believe the presence of injustice in the workplace, they do not want to do their work and they try to find a way to cop-out. Cyberloafing is the least noticeable and the least risky of these ways of cop-out. For these reasons, the perceived lack of organizational justice may cause cyberloafing.

In the light of the above mentioned facts the objective of this research is to determine the relationship between the lack of organizational justice and cyberloafing. 


\section{The Concept of Organizational Justice}

Organizational justice refers to "the individuals' perceptions of justice in organizations" (Schmiesing, Safrit, \& Gliem 2003; 28). Employees who work in a fair organization, regard the managers' behaviours as fair, ethical and rational (İscan and Naktiyok, 2004; 7). Organizational justice is a basic need for an effective process of personal satisfaction of the organizations and their employees. It is also effective in employees' behaviours towards organizations (Lambert, 2003; 155).

Organizational justice is individuals' opinion about how fairly they are behaved in the organization. The researches about organizational justice show that people are more interested in the social aspect of justice. It is indicated that fair behaviour in organizations attach individuals to each other and to organizations. When the employees in an organization feel that the manager behaves them fairly, the collaboration becomes easier and the employees support the decisions of their managers. However, in the case of injustice, individuals try to take revenge on each other, apply to legal procedures and behave each other aggressively.

\subsection{Perceptions of Organizational Justice and Dimensions}

Scientists agreed on the three types of organizational justice. These are distributive justice, procedural justice and interactional justice.

\subsubsection{Distributive Justice}

Distributive justice refers to employees' perception of fairness of the obtained results (Greenberg, 1990; 399). Employees can make a decision about the fairness of distribution at work by comparing their earnings to their colleagues' earnings. Distributive justice is a concept related to the employees' perceptions of earnings and decisions (promotion and pay rise) in organizations as fair and equal (Robinson, 2004; 10).

Consistency is important in distributive justice. Being consistent means not being prejudiced and not attaching importance to personal profits, being built on accurate information and using accurate information in distributive decisions (Jones, Scarpello, \& Bergmann, 1999; 131).

\subsubsection{Procedural Justice}

Procedural justice is a concept related to the fairness of the procedures which are the most significant means to make a decision. Procedures are the means used to reach a desired conclusion. On the contrary to distributive justice whose subject-matter is the fairness of decisions, the subject of procedural justice is the processes causing to these decisions (İşbaşı, 2001; 61 in Folger, 1987).

The perception of procedural justice will be high in the organizations where the employees are effective in the process of decision making or where they approve the decisions which are taken (Greenberg and Baron, 2000; 145).

\subsubsection{Interactional Justice}

Interactional justice is about the human aspect of organizational practices. In other words, it is about what and how the managers tell individuals in the process of taking decision (Dilek, 2004).

Interactional justice has been introduced by Bies and Moag. One of the basic points of fair interaction perception is to show sufficient and valid reasons for the decision taken. In addition to this many researches argue that the oral explanations rather than written ones about the decisions increase the individuals' perceptions of justice (Konovsky, 2000).

\section{The Concept of Cyberloafing}

Cyberloafing is non-work related use of Internet and e-mail by the employees of a company in the work hours (Lim, 2002). Cyberloafing is accepted to be harmless as long as it is for a limited time. The common points of the definitions of cyberloafing are that it is to be busy with personal activities on the Internet during work hours for non-work related 
purposes. Academicians usually regard cyberloafing behaviours as a way of digression from work (Lim, 2002; Lim and Teo, 2005).

Ugrin, Pearson and Odom (2008) stated that there is a meaningful loss of efficiency in an organization as a result of cyberloafing behaviours while Philips and Reddie (2007) indicated that these behaviours caused a problem in the efficient use of time and in the employees' performance of their duties.

However some of the recent researches have shown out that cyberloafing can be relaxing and releasing service for the employees in order to come over the stress at work. For instance, Lim and Chen (2009) have found out that searching websites for personal purposes at work can help to increase the efficiency by refreshing the minds of employees.

Menzel (1998) stated that activities such as surfing on the Internet for fun, downloading and examining obscene things, sending e-mails by using nicknames are the behaviours which the managers of public institutions in the USA confront and which are accepted to be undesirable and inefficient behaviours. Besides the direct costs, the reason for the costs which are not material such as the decrease in the efficiency of the workers might be the misuse of the Internet. For example, most of the 150 managers participated in a research indicated that the cause of the decrease in the efficiency of their employees is using the Internet for special purposes which are not related to work (Roman,1996).

Moreover in another research, it is stated that the use of Internet at work for personal reasons might reduce the efficiency of the employees by 30-40 per cent (Verton,2000). When all the information from these researches is analyzed together, the numbers related to the misuse of the Internet by the employees or at least the potential of the employees in this matter is clearly noticed.

\section{The Relationship Between Perceived Organizational Justice and Cyberloafing}

The employees working in a business are observed to be trying to compensate perceived lack of organizational justice by dodging. If there is a lack in distributive, procedural or interactional justice, employees tend to display dodging behaviours more in return. In such a situation, employees may choose to cop-out in order to take revenge on their managers who display unfair behaviour to them or choose to punish their managers in this way. Dodging behaviours such as long coffee or lunch breaks, chatting to each other for a long time, pretending as working while they are not working have started to appear as cyberloafing by the development of technology.

Since technology is used more in businesses nowadays, the use of Internet has appeared to be an indispensable element of companies. While the employees do their work by means of the Internet, they can suddenly start surfing on the non-work related websites as Internet has an immense world. If the employees are exposed to unfair behaviours of their managers, they start to display cyberloafing behaviours intentionally.

\section{Methodology}

The aim of this research is to reveal the impact of the perception of organizational justice on cyberloafing in hospitals. In this research the organizational justice has been discussed in three dimensions. These are distributive justice, procedural justice and interactional justice. In this research the effect of the perception of organizational justice on the tendency of displaying cyberloafing behaviours has been examined. The survey technique has been applied as a data gathering method in this research. The survey consists of three parts. In the first part, demographic features of the employees in the health industry have been determined. The second part includes questions that measure employees' perceptions of organizational justice. The questions in this part have been prepared by adapting the 11 questions of Niehoff and Moorman used by Yıldırım (2002) to the employees in hospitals. The third part of the survey includes questions about cyberloafing. The questions in this part have been taken from the scale prepared by Lim (2002) and they have been applied to the employees in hospitals. All the statements in the survey are answered in the form of 5-point Likert scale ( 1 =strongly disagree, $5=$ =strongly agree). The study has taken place in a university hospital in Konya. A questionnaire has been distributed to 130 randomly selected employees. 119 of these questionnaires have been returned and 4 out of these have been excluded due to various deficiencies. A total of 115 questionnaires have been evaluated. Hypotheses of the study are as follows:

- Hypothesis 1: Organizational justice has three sub dimensions as procedural justice, distributive justice and interactional justice.

- Hypothesis 2 : Organizational justice has a negative impact on cyberloafing. 
Structural equation modelling (SEM) has been used in testing of conceptual model of the research. SEM is an effective model testing method, which can explain the cause and effect relationship between variables, and allows theoretical models to be tested as a whole (Ayyildiz, Cengiz and Ustasuleyman, 2006). SPSS-AMOS 6.0 program was used at the stage of SEM analysis.

Figure 1: General model of the research

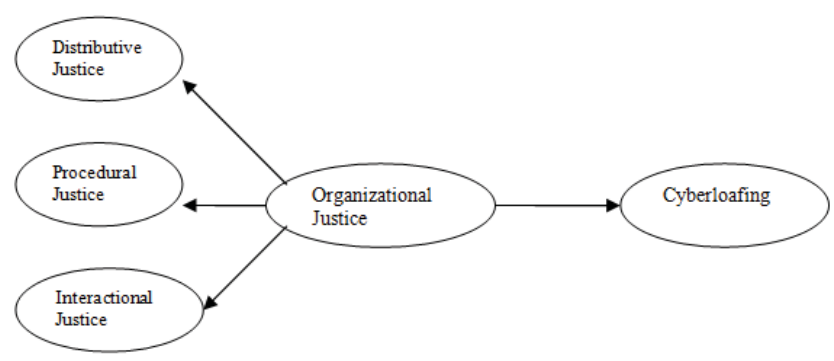

In this model the organizational justice has been analyzed in three dimensions as distributive justice, procedural justice and interactional justice. The effect of the perception of organizational justice on displaying cyberloafing behaviours has been examined.

\section{Research Findings}

In this section research findings will be summarized under four different titles. These are: the characteristics of the sampling, exploratory factor analysis, confirmatory factor analysis and structural equality analysis.

\subsection{The Characteristics of the Sampling}

The demographic characteristics of the employees have been evaluated in the context of the research given in Table 1.

Table 1: The Demographic Characteristics of the Employees Participating to the Survey

\begin{tabular}{|c|c|c|c|c|c|c|c|c|}
\hline Characteristics & $f$ & $\%$ & Characteristics & f & $\%$ & Characteristics & f & $\%$ \\
\hline $\begin{array}{l}\text { Gender } \\
\text { Female } \\
\text { Male }\end{array}$ & $\begin{array}{l}66 \\
49\end{array}$ & $\begin{array}{l}57,4 \\
42,6\end{array}$ & $\begin{array}{l}\text { Occupation } \\
\text { Doctor } \\
\text { Nurse } \\
\text { Technical Personnel } \\
\text { Secretary }\end{array}$ & $\begin{array}{l}34 \\
45 \\
16 \\
20\end{array}$ & $\begin{array}{l}29,6 \\
39,1 \\
13,9 \\
17,4\end{array}$ & $\begin{array}{l}\text { Educational Level } \\
\text { High school } \\
\text { Associate's } \\
\text { Bachelor's degree } \\
\text { Post Graduate }\end{array}$ & $\begin{array}{l}13 \\
51 \\
28 \\
23\end{array}$ & $\begin{array}{l}11,3 \\
44,3 \\
24,3 \\
20,0\end{array}$ \\
\hline Total & 115 & 100,0 & Total & 115 & 100,0 & Total & 115 & 100,0 \\
\hline
\end{tabular}

\subsection{Exploratory Factor Analysis (EFA)}

For analysis of the research model, reliability analysis and exploratory factor analysis (EFA) have been performed first. At the second stage of the analysis, in order to verify dimensions identified by the exploratory factor analysis, confirmatory factor analysis (CFA) has been carried out. Before examining the research model by structural analysis, unidimensionality of variables in the model has been examined by means of EFA and internal consistency, in other words, reliability of dimensions has been evaluated. Table 2, Cronbach alpha (a) values of each dimension in scales and variance explained (VE) by each dimension are given in brackets. Factor loads of items measuring each dimension and other values are also shown. To calculate factor loads for all scales in EFA, maximum likelihood estimation method and direct oblimin rotation technique have been applied, factors with eigenvalue greater than 1 have been taken into account and factor loadings were stipulated to be greater than 0.50 . Before starting EFA, so as to increase reliability of scales, total correlations of items have been evaluated and KMO values testing suitability of sample size for factor analysis and Barlett Sphericity Chi-Square Test values testing suitability of data to factor analysis have been calculated. It has been 
stipulated that KMO value should be greater than 0.60 and Chi-square value should be meaningful. For reliability analyses, Cronbach alpha values have been stipulated to be equal to or greater than 0.70 .

Table 2: Exploratory Factor Analysis

\begin{tabular}{|c|c|c|}
\hline Factors & Item & $\begin{array}{c}\text { Factor } \\
\text { loadings }\end{array}$ \\
\hline \multicolumn{3}{|c|}{ Organizational Justice } \\
\hline \multicolumn{3}{|c|}{ Procedural Justice $(\alpha=0,938 ;$ V.E=\%38,995) } \\
\hline & İsl1 & 0,930 \\
\hline & İsl2 & 0,925 \\
\hline & İsl3 & 0,921 \\
\hline & İs|4 & 0,927 \\
\hline \multicolumn{3}{|c|}{ Distributive Justice ( $\alpha=0,962 ; \mathrm{V} . \mathrm{E}=\% 28,530)$} \\
\hline & Da1 & 0,905 \\
\hline & Da2 & 0,930 \\
\hline & Da3 & 0,917 \\
\hline \multicolumn{3}{|c|}{ Interactional Justice ( $\alpha=0,942 ; \mathrm{V} . \mathrm{E}=\% 32,650)$} \\
\hline & Ea1 & 0,945 \\
\hline & Ea2 & 0,934 \\
\hline & Ea3 & 0,935 \\
\hline & Ea4 & 0,916 \\
\hline \multicolumn{3}{|c|}{$\begin{array}{l}\mathrm{N}=115 ; \mathrm{KMO}=0,718 ; \\
\text { Bartlett Sph. Test Chi-Square=951,139, } \mathrm{p}=0,000 \\
\text { Total Variance Explained }=\% 94,952 \text { Factor Loadings } \geq 0,50\end{array}$} \\
\hline \multicolumn{3}{|c|}{ Cyberloafing ( $\alpha=0,955 ;$ V.E=\%84,351) } \\
\hline & Cyb1 & 0,894 \\
\hline & Cyb2 & 0,903 \\
\hline & Cyb3 & 0,972 \\
\hline & Cyb4 & 0,903 \\
\hline \multicolumn{3}{|c|}{$\begin{array}{l}\mathrm{N}=115 ; \mathrm{KMO}=0,859 ; \\
\text { Bartlett Sph. Testi Chi-Square }=521,588, \mathrm{p}=0,000 \\
\text { Total Variance Explained }=\% 88,986 \text { Factor Loadings } \geq 0,50\end{array}$} \\
\hline
\end{tabular}

Total explained variance of organizational justice scale among the findings of our research is about $95 \%$. It shows that the scale measures these behaviours quite well. Moreover total explained variance of cyberloafing scale has been found out about $89 \%$.

\subsection{Confirmatory Factor Analysis (CFA)}

CFA, which is used in verification of factors and/or dimensions defined in EFA and testing the reliability and validity of the scale, calculates some values showing the statistically significance and compatibility of the proposed model. In Table 3, items included in dimensions of all scales and their standardized loadings, t-values and significance levels corresponding to t-values are shown. Additionally, structural reliability $(\rho \eta)$ and explained variances (VE) are specified in brackets against each dimension (structure). Structural reliability must be greater than 0.70 and explained variances must be greater than 0.50 (Fornell and Larcker, 1981; Hair, Andreson, Tahtam, \& Black, 1998).

\section{Table 3: First Level Confirmative Factor Analysis Results For Organizational Justice}

\begin{tabular}{|l|c|c|c|c|}
\hline Organizational Justice & $\begin{array}{c}\text { Item } \\
\text { No }\end{array}$ & $\begin{array}{c}\text { Std. Reg. } \\
\text { weight }\end{array}$ & $t$ & $p$ \\
\hline Dimensions & \multicolumn{1}{|l|}{} & & \\
\hline Procedural Justice $\left(\rho_{\eta}=0,98 ;\right.$ V.E=0,93) &, 919 & & \\
\hline & İsl2 &, 962 & 10,839 & $<0,001$ \\
\hline & İsl3 &, 921 & 10,655 & $<0,001$ \\
\hline
\end{tabular}




\begin{tabular}{|l|c|c|c|c|}
\hline & İsl4 &, 927 & 11,012 & $<0,001$ \\
\hline Distributive Justice $\left(\rho_{\eta}=0,96 ;\right.$ V.E=0,88) & Da1 &, 962 & & \\
\hline \multicolumn{7}{|l|}{} & Da2 &, 958 & 19,578 & $<0,001$ \\
\hline & Da3 &, 917 & 19,631 & $<0,001$ \\
\hline \multicolumn{7}{|l|}{} & Ea1 &, 945 & & \\
\hline Interactional Justice $\left(\rho_{\eta}=0,97 ;\right.$ V.E=0,91) & Ea2 &, 934 & 14,142 & $<0,001$ \\
\hline & Ea3 &, 935 & 15,153 & $<0,001$ \\
\hline & Ea4 &, 916 & 14,245 & $<0,001$ \\
\hline
\end{tabular}

Table 4: Confirmative Factor Analysis for Cyberloafing

\begin{tabular}{|c|c|c|c|c|}
\hline Dimension & $\begin{array}{c}\text { Item } \\
\text { No }\end{array}$ & $\begin{array}{c}\text { Std. Reg. } \\
\text { weight }\end{array}$ & $t$ & $p$ \\
\hline Cyberloafing $\left(\rho_{n}=0,95 ;\right.$ V.E=0,85) \\
\hline & Cyb1 & 0,901 & ----- & 0,000 \\
\hline & Cyb2 & 0,910 & 15,797 & 0,000 \\
\hline & Cyb3 & 0,973 & 18,921 & 0,000 \\
\hline & Cyb4 & 0,911 & 15,811 & \\
\hline
\end{tabular}

Table 5: Second level confirmative factor analysis for organizational justice

\begin{tabular}{|c|c|c|c|}
\hline Dimensions & Std. Reg. Weight & $t$ & $p$ \\
\hline Distributive Justice & 0,811 & 7,066 & $<0,001$ \\
\hline Procedural Justice & 0,735 & 6,144 & $<0,001$ \\
\hline Interactional Justice & 0,641 & ---- & \\
\hline
\end{tabular}

When tables are reviewed, it is seen that structural reliability values and explained variances of each model are greater than 0.70 and 0.50 , respectively. The t-values corresponding to standardized loadings of items representing each dimension are found to be statistically significant. All dimensions found in the exploratory factor analysis are identified in the confirmative factor analysis as well.

Second level CFA is an evaluation carried out to examine correlation between dimensions and sub variables of such dimensions. According to second level CFA performed for organizational justice scale, organizational justice is verified to consist of three sub-dimensions as in literature. It is understood that the most perceived dimension among these three dimensions is distributive justice with a value of 0.811 .

Hypothesis 1: Organizational justice has three sub dimensions as procedural justice, distributive justice and interactional justice.

Hypothesis 1 is ACCEPTED.

\subsection{Structural Equality Analysis}

Following identification and verification of sub-dimensions of main variables included in the research model, structural equality analysis was carried out at the stage of testing the structural model. Before evaluation of correlations in the conceptual model, it is needed to determine whether the model is significant and valid in statistical terms. Compatibility measurements included in the confirmative factor analysis are also applicable for the structural model and are given in Table 6.

Table 6: Compatibility measures for the structural model

\begin{tabular}{|c|c|c|c|}
\hline $\begin{array}{c}\text { Compatibility } \\
\text { measure }\end{array}$ & $\begin{array}{c}\text { Good } \\
\text { compatibility }\end{array}$ & $\begin{array}{c}\text { Acceptable } \\
\text { compatibility }\end{array}$ & Model proposed \\
\hline $\mathrm{RMSEA}$ & $0<\mathrm{REMSEA}<0,05$ & $0,05 \leq \mathrm{RMSEA} \leq 0,10$ & 0,04 \\
\hline $\mathrm{NFI}$ & $0,95 \leq \mathrm{NFI} \leq 1$ & $0,90 \leq \mathrm{NFI} \leq 0,95$ & 0,96 \\
\hline $\mathrm{CFI}$ & $0,97 \leq \mathrm{CFI} \leq 1$ & $0,95 \leq \mathrm{CFI} \leq 0,97$ & 0,99 \\
\hline
\end{tabular}




\begin{tabular}{|c|c|c|c|}
\hline $\mathrm{GFI}$ & $0,95 \leq \mathrm{GFI} \leq 1$ & $0,90 \leq \mathrm{GFI} \leq 0,95$ & 0,92 \\
\hline $\mathrm{AGFI}$ & $0,90 \leq \mathrm{AGFI} \leq 1$ & $0,85 \leq \mathrm{AGFI} \leq 0,9$ & 0,88 \\
\hline$\chi^{2 / \mathrm{df}}$ & \multicolumn{2}{|c|}{$0<\chi^{2} / \mathrm{df}<3$} & $50,128 / 40=1,253$ \\
\hline
\end{tabular}

When the table above is reviewed, RMSEA, NFI and CFI amongst compatibility measures for the structural model are within the limits of good compatibility. GFI and AGFI values are within the range of acceptable compatibility limits. These results show that the developed conceptual model complies with the data and the model is valid and meaningful in statistical terms.

Figure 2: SEM analysis results for the conceptual model

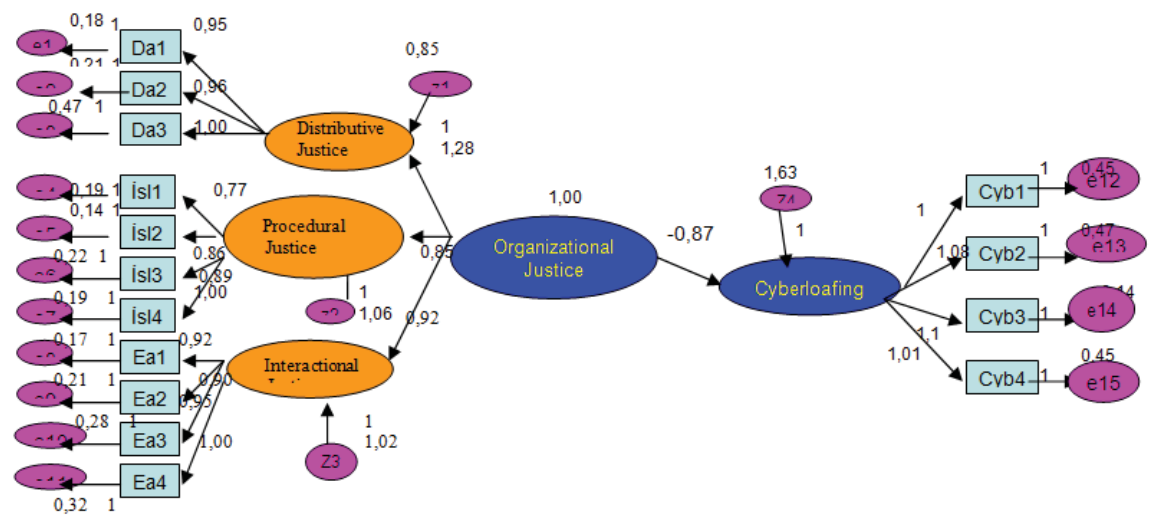

When Structural Equality Modelling in Figure 2 is examined, it is understood that there is a negative relation between the perception of organizational justice and cyberloafing. The relation between the perception of organizational justice and cyberloafing is $-0,87$. According to this result the perception of organizational justice affects cyberloafing negatively. In other words, when the perception of organizational justice is high, cyberloafing behaviour decreases. According to this analysis;

Hypothesis 2 : Organizational justice has a negative impact on cyberloafing.

Hypothesis 2 is ACCEPTED.

\section{Conclusion}

People confront different things in their business life as the time passes. While managers consider to be using the most accurate method for both themselves and their businesses, employees might think these practices to be wrong or unfair. The perception of justice has a significant importance in organizations. The employees' performance, efficiency and attachment to the organization are affected by the level of justice in business. The employees who are in the opinion of an injustice in the organization might react to this injustice in different ways. These reactions may vary from person to person and from business to business. The most common of these reactions recently is cyberloafing.

Employees have applied to different ways to cop-out at work before; however, they choose to chat their friends on the Internet or to surf on the websites that are not related to work. These cop-out behaviours cause a decrease in the efficiency of the worker and an inefficient use of time. Nowadays the number of the employees cyberloafing is quite high. Some of these choose this way because of boredom while the others apply to it as a reaction to management.

In our research aiming to assess the effect of the perception of organizational justice in hospitals on cyberloafing behaviours, it has been concluded that employees avoid displaying cyberloafing behaviours when their perception of organizational justice is high. On the other hand, it has been recognized that employees display cyberloafing behaviours when they think that there is an unfair manner in the organization.

The researches conducted show out that the rate of cyberloafing in fair organizations is lower than the rate in other organizations. As a result, it will not be wrong to state that cyberloafing behaviours might occur as a reaction to organizational injustice. 
No matter, what the reason is, it is required to reduce the use of non-work related Internet to minimum level. There are some suggestions for this matter:

- Providing organizational justice

- Identifying and warning the employees who are cyberloafing

- Using the programmes enabling to use only some specific websites on the computers used in the organization

- Giving employees a right to speak during the process of decision taking

Owing to these mentioned precautions, cyberloafing behaviours in businesses will decrease and the efficiency will increase. However, another thing to be realized is that if justice is not provided in a business, employees will apply to different ways to cop-out at work even if cyberloafing is prevented. For this reason, the priority should be to provide organizational justice.

\section{References}

Ayyildiz, H, Cengiz, E., \& Ustasuleyman, T. (2006). A Structural Model Proposal For Effect Of Behavioral Variables Between Employees In Manufacturing And Marketing Departments On Business Performance. Mugla Univ. J. Soc. Sci., 17:21-38.

Bock, G. W., Ho, S. L. (2009). Non-Work Related Computing (NWRC). Communications of the ACM, 52,124-128.

Dilek, U. (2004). The Perceptions Of Organizational Justice And Their Relation To Organizational Attachment. Unpublished master's thesis, Military Academy, Institute for Defence Sciences, Ankara, Turkey.

Fornell, C., Larcker, D.F. (1981). Evaluating Structural Equation Models with Unobservable Variables and Measurement Error. Journal of Marketting Research.,18(1): 39-50.

Greenberg, J. (1990). Organizational Justice: Yesterday, Today And Tomorrow. Journal of Management, 16, 339-342.

Greenberg, J., Baron, R. A. (2000). Behavior In Organizations. Prentice Hall Inc., New Jersey, USA.

Hair, J.F., Andreson R.E., Tahtam R.L., \& Black C.W. (1998). Multivariate Data Analysis. Fifth Edition Prentice-Hall International Inc. New Jersey.

İşbaşı, J. Ö. (2001). Çalışanların Yöneticilerine Duydukları Güvenin Ve Örgütsel Adalete Illişkin Algılamalarının Vatandaşlık Davranışının Oluşumundaki Rolü. Yönetim Araştırmaları Dergisi, 1 (1), 51-73.

İşcan, Ö. F., Naktiyok A. (2004). Çalışanların Örgütsel Bağdaşımlarııın Belirleyicileri Olarak Örgütsel Bağılıık Ve Örgütsel Adalet Algısı. [On-line]. Available: www.politics.ankara.edu.tr/dergi, 1-14 [November 07,2011]

Johnson, P. R., Indvik, J. (2004). The Organizational Benefits Of Reducing Cyberslacking in The Workplace. Journal of Organizational Culture, Communications, and Conflict, 8, 55-62.

Jones, F. F., Scarpello, V., \& Bergmann, T. (1999). Pay Procedures - What Makes Them Fair? Journal of Occupational and Organizational Psychology, $72(2), 129-145$.

Konovsky, M. A. (2000). Understanding Procedural Justice And Its Impact On Business Organizations. Journal of Management, 26 (3), 489-511.

Lambert, E. (2003). The Impact of Organizational Justice On Correctional Staff. Journal of Criminal Justice, 31, 155-168.

Lim, V. K. G. (2002). The It Way Of Loafing On The Job: Cyberloafing, Neutralizing And Organizational Justice. Journal of Organizational Behaviour, 23, 675-694.

Lim, V. K. G., Chen, D. J. Q. (2009). Cyberloafing At The Workplace: Gain Or Drain On Work? Behaviour \& Information Technology, 25(1), 1-11.

Lim, V. K. G., Teo, T. S. H. (2005). Prevalence, Perceived Seriousness, Justification And Regulation of Cyberloafing in Singapore: An Exploratory Study. Information \& Management, 42(8), 1081-1093.

Mastrangelo, P.M., Everton, W., \& Jolton, J. A. (2006). Personal Use Of Work Computers: Distraction Versus Destruction. CyberPsychology \& Behavior, 9, 730-741.

Menzel, D. C. (1998). Issues and Challenges Facing Public Managers. Public Administration Review, 58, 445-452.

Phillips, J. G., Reddie, L. (2007). Decisional Style And Self-Reported E-Mail Use In the Workplace. Computers in Human Behavior, 23(5), 2414-2428.

Robinson, K. L. (2004). The Impact Of İndividual Differences On The Relationship Between Employee Perceptions Of Organizational Justice And Organizational Outcome Variables, 1-156. Dissertation, Alliant International University, San Diego.

Roman, L.A. (1996). Survey: Employees Traveling In Cyberspace While On The Clock. Memphis Business Journal, 10, 2-3.

Schmiesing, R.J., Safrit, R.D., \& Gliem, J.A. (2003). Factors affecting O.S.U. extension agents' preceptions of organizational justice and job satisfaction. Journal of International Agricultural and Extension Education, 10 (2), 25-31.

Ugrin, J.C., Pearson, J.M., \& Odom, M.D. (2008). Profiling Cyber-Slackers In The Workplace: Demographic, Cultural, And Workplace Factors. Journal of Internet Commerce, 6 (3), 75 -89.

Verton, D. (2000). Employers Ok With E-Surfing. Computerworld, 34 (1), 16.

Yıldııım, F. (2002). Çalışma Yaşamında Örgütsel Bağılıık Ve Örgütsel Adalet Ilişskisi. Yayımlanmamış Doktora Tezi, Ankara Üniversitesi Sosyal Bilimler Enstitüsü, Ankara. 